\title{
Concordance of the diagnosis of the surgeon with histopathological diagnosis in adult patients surgical intervention by acute appendicitis
}

\author{
Concordancia del diagnóstico del cirujano con el diagnóstico histopatológico en \\ pacientes adultos intervenidos quirúrgicamente por apendicitis aguda
}

\author{
Gamaliel Vázquez-Estudillo ${ }^{* *}$, Edwin Y. Ochoa-Viveros ${ }^{1}$, Ivanhoe Larracilla-Salazar ${ }^{1,2}$, \\ Gerardo Rodarte-Cajica ${ }^{2}$ and Murata Chiharu ${ }^{3}$ \\ ${ }^{1}$ General Surgery Specialty, Escuela de Graduados en Sanidad Naval; ${ }^{2}$ General Surgery Department, Hospital General Naval de Alta Especialidad; \\ ${ }^{3}$ Methodology Specialty, Escuela de Graduados en Sanidad Naval. Mexico City, Mexico
}

\begin{abstract}
Objective: To identify the concordance of the macroscopic diagnosis with the histopathological diagnosis in patients surgically treated for Acute Appendicitis (AA) in the Naval General Hospital of High Specialty (HOSGENAES). Methods: All the patients with probable AA operated on appendectomy, in the general surgery service of the HOSGENAES, the histopathological report was recovered with support of the HIS-2 electronic file system of the hospital, the agreement was made by Cohen's kappa index. Results: In this study of 200 cases of AA, when categorized by groups in relation to the AA phase in the postoperative period, $5(2.5 \%)$ cases were diagnosed by the surgeon as appendages apparently healthy or without inflammatory signs, 73 (36.5\%) as congestive AA or catarrhal, 97 (48.5\%) as phlegmonous or suppurative, $20(10 \%)$ as gangrenous or necrotic and $5(2.5 \%)$ as perforated. Histopathological diagnosis yielded the following figures: $10(5 \%)$ cases of appendices without inflammatory signs, 61 (30.5\%) cases of congestive or catarrhal AA, 107 (53.5\%) phlegmonous or suppurative, 11 (5.5\%) as gangrenous or necrotic and 11 (5.5\%) as perforated. Conclusions: We obtained a low concordance (kappa: 0.18 ) in the diagnosis of $A A$ among surgeons and pathologists when classifying it by phases.
\end{abstract}

Key words: Appendicitis. Appendectomy. Concordance.

\section{Resumen}

Objetivo: Identificar la concordancia del diagnóstico macroscópico con el diagnóstico histopatológico en pacientes intervenidos quirúrgicamente por apendicitis aguda (AA) en el Hospital General Naval de Alta Especialidad (HOSGENAES). Método: De los pacientes con probable AA operados de apendicetomía en el servicio de cirugía general del HOSGENAES se recuperó el reporte histopatológico con apoyo del archivo electrónico HIS-2 del hospital. La concordancia se realizó por el índice kappa de Cohen. Resultados: En este estudio de 200 casos de AA, al categorizar por grupos en relación a la fase de AA fueron diagnosticados por el cirujano 5 (2.5\%) casos como apéndices aparentemente sanos o sin signos inflamatorios, $73(36.5 \%)$ como AA congestiva-catarral, 97 (48.5\%) como flemonosa-supurada, 20 (10 \%) como gangrenosa-necrosada y

\section{Correspondence:}

*Gamaliel Vázquez-Estudillo

Calzada de la Virgen 203 int. 104

Col. Culhuacán CTM, Del. Coyoacan

Date of reception: $04-04-2018$

C.P. 04480, Ciudad de México, México

E-mail: dr.gama.mcn@gmail.com
Cir Cir. 2018;86(6):654-658

Contents available at PubMed

www.cirugiaycirujanos.com

0009-7411/@ 2018 Academia Mexicana de Cirugía. Published by Permanyer. This is an open access article under the terms of the CC BY-NC-ND license (http://creativecommons.org/licenses/by-nc-nd/4.0/). 
5 (2.5\%) como perforada. El diagnóstico histopatológico arrojó las siguientes cifras: 10 (5\%) casos de apéndices sin signos inflamatorios, 61 (30.5\%) casos de AA congestiva o catarral, 107 (53.5 \%) flemonosa o supurada, 11 (5.5\%) como gangrenosa o necrosada, y 11 (5.5\%) como perforada. Conclusiones: Se obtuvo una baja concordancia (kappa: 0.18) en el diagnóstico de $A A$ entre cirujanos y patólogos al clasificarla por fases.

Palabras clave: Apendicitis. Apendicectomía. Concordancia.

\section{Introduction}

Appendectomy is currently the most common emergency surgical procedure in the world; the estimated risk for suffering from appendicitis sometime in life is $8.6 \%$ for men and $6.7 \%$ for women. It has an incidence of 1.5 a 1.9 cases per 1000 population, and the most affected population is between 15 and 35 years of age. One in 15-20 Mexicans will experience acute appendicitis (AA) sometime in life, and in our hospital nearly 800 appendectomies have been performed in the last 5 years, which makes for it to be one of the most common surgical procedures, just as in the reported literature'.

$\mathrm{AA}$ is the most common emergency surgical pathology in our setting; however, it continues to be a diagnostic challenge for health professionals even with all the highly sensitive and specific complementary diagnostic studies'.

Various diagnostic scales have been proposed and created for $A A$, with the Alvarado scale being the best known and most widely used, given that its use has been validated in numerous studies. To date, a specific and reliable marker has not yet been identified for AA. Despite advances in technology and research modalities, the percentage of negative appendectomies remains between 15 and $50 \%$. The studies show that there is a certain benefit when performing a tomography in patients who have abdominal pain with few clinical data suggestive of $A A$, since the criteria used in the Alvarado scale most of the time appear at late stages of appendicitis'.

It is widely known that appendicitis suspicion is clinical; it is integrated by history taking, physical examination, laboratory tests and imaging studies; and is corroborated by histopathological examination, once the surgical procedure is performed, it is staged by the surgeon according to macroscopic phases (phase $0-I V$ ), but this classification sometimes differs from histopathological reports.

The appendicitis phase is not confirmed until postoperative findings are available. In a standardized way, the phase determines the number of days of pharmacological treatment, the number days of hospital stay and possible complications; final histopathological diagnosis can modify this evolution. We consider prudent the search for agreement in the diagnoses, since it is related to appropriate treatment, days of hospital stay, days of recovery and possible complications. Failure to establish an early diagnosis increases disease mortality and morbidity as well as the risk of complications. A delayed diagnosis increases emergency department and hospital $\operatorname{costs}^{2,3}$.

Severity of appendicitis can be determined by the macroscopic appearance and by histopathological examination. Through macroscopic observation of surgical findings, it can be classified as follows: phase 0 , no appendicitis; phase I, congestive or catarrhal appendicitis, where hyperemia is appreciated; phase II, phlegmonous or suppurative appendicitis, i.e., with erosions of the mucosa, suppuration and fibrinopurulent exudates; phase III, necrotized appendicitis or with gangrenous wall; and phase IV, perforated appendicitis. Although to date there is no unique model with regard to clinical classification, in some hospitals it is valid for histopathological classification ${ }^{4-7}$.

Pharmacological management is related to $A A$ stage, and there are various treatments and regimens. Cases of uncomplicated AA at phases I and II (congestive and phlegmonous) require short hospital stay and antibiotic treatment, in some cases for 24 hours or less; regarding the treatment of complicated acute appendicitis at phases III and IV (gangrened and perforated), they require a 72-hour hospital stay and double antibiotic treatment, for 7 to 10 days, which starts with the subject as inpatient and with management by oral route for follow-up on an outpatient basis ${ }^{8-12}$.

Knowing the percentage of cases in which AA histopathological diagnosis is confirmed and its correlation with macroscopic diagnosis in our institution will help the application of the ideal antibiotic treatment regimen, since it is dependent on the $A A$ phase ${ }^{13-17}$. 
In the Naval Secretariat of Mexico, it is priority keeping military personnel in top health conditions for their performance in different activities, and in the case of experiencing pathologies of surgical resolution, the goals we pursue are to reduce hospital stay, complications and comorbidity, both for active and retired Navy members and their families, hence the importance of adequate macroscopic classification when the surgical procedure is carried out and concordance of final diagnosis, which undoubtedly is the histopathological report.

\section{Method}

A quantitative cross-sectional, non-experimental study was carried out, in the period comprised from September 2015 to August 2017, with all surgically intervened patients with AA diagnosis who attended for medical assessment and received surgical treatment at the Naval High Specialty General Hospital (HOSGENAES - Hospital General Naval de Alta Especialidad), which include people aged 16 to 65 years, who were active or retired military, affiliates and non-affiliates.

The study variables were gender, age, macroscopic appendicitis phases and histopathological classification. The classification used was the following: no appendicitis, congestive or catarrhal, phlegmonous or suppurated, gangrenous or necrotic, and perforated.

Calculated sample size was 193 patients $^{18-20}$. The $95 \%$ level of confidence was established with a kappa margin of error \pm 0.15 .

Once the research protocol was approved, patients were recruited with support of the HOSGENAES general surgery department medical staff. Information on the diagnosis issued by the surgeon in the postoperative note and on histopathological diagnosis in the pathology department reports was collected, with support of the HIS-2 electronic records system of the hospital.

The analysis of macroscopic and histopathological diagnoses agreement was carried out using Cohen's kappa index.

\section{Results}

This study of 200 AA cases had a higher proportion of female patients, with 114 versus 86 male patients.

The highest incidence of appendicular clinical presentation occurred in patients between the third and fourth decades of life, with the majority being of the
Table 1. Acute appendicitis phases according to macroscopic and histopathological diagnoses in patients undergoing appendectomy

\begin{tabular}{|c|c|c|c|c|c|c|c|}
\hline \multicolumn{8}{|c|}{ Histopathological diagnosis } \\
\hline \multirow{7}{*}{ 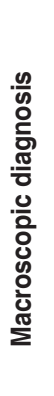 } & & 0 & 1 & 2 & 3 & 4 & Total \\
\hline & 0 & 2 & 3 & 0 & 0 & 0 & 5 \\
\hline & 1 & 7 & 26 & 39 & 1 & 0 & 73 \\
\hline & 2 & 1 & 32 & 60 & 3 & 1 & 97 \\
\hline & 3 & 0 & 0 & 8 & 6 & 6 & 20 \\
\hline & 4 & 0 & 0 & 0 & 1 & 4 & 5 \\
\hline & Total & 10 & 61 & 107 & 11 & 11 & 200 \\
\hline
\end{tabular}

third decade, with a total of 87 cases, and an age range of 45 years between the youngest (15 years) and the oldest patient (60 years).

When categorizing by groups in relation to the $A A$ phase in the postoperative period, $5(2.5 \%)$ were diagnosed by the surgeon as apparently healthy appendices or without inflammatory signs, $73(36.5 \%)$ as congestive or catarrhal AA, 97 (48.5\%) as phlegmonous or suppurated, $20(10 \%)$ as gangrenous or necrotic, and $5(2.5 \%)$ as perforated AA (Table 1). Histopathological diagnosis yielded the following resulting figures: $10(5 \%)$ appendices without inflammatory signs, $61(30.5 \%)$ congestive or catarrhal AA, 107 $(53.5 \%)$ phlegmonous or suppurated, 11 (5.5\%) gangrenous or necrotic, and 11 (5.5\%) perforated $\mathrm{AA}$ (Table 1).

\section{Discussion}

AA diagnosis improves over the years of the surgeon's practice, due to his/her experience and to the advances in medicine in auxiliary studies, mainly imaging. Despite all this, it is not uncommon finding an apparently healthy appendix during surgical intervention in a patient with presumptive AA diagnosis. Neither is it uncommon not to find a cause that justifies the right iliac fossa pain on abdominal examination in these patients ${ }^{3}$.

The percentage of negative appendectomies considering the surgeon's point of view was $5 \%$, similar to that referred by Kulikoff et al. ${ }^{21}$ in their study of 782 pediatric cases, which increased to $10 \%$ when it was compared with the pathological anatomy result. Both studies differ from observations reported by Ávila and 
García ${ }^{22}$ in Colombia, who refer $18.1 \%$ of negative appendectomies. It is important highlighting that the value reported in our study is below $12-15 \%$ of laparotomies referred to as blank or negative, which is considered tolerable from the surgical point of view as indicated by the committee for development of clinical practice guidelines of the Mexican Association of General Surgery ${ }^{1}$. Nevertheless, it is necessary bearing in mind that obtaining less than $12 \%$ of negative appendectomies should also be of concern, since it could mean that patients with atypical AA should be left under observation and be operated when they already have any complication.

By categorizing AA by phases, a low inter-observer agreement was obtained (kappa: 0.181085 ), similar to that reported by Segovia and Figueredo ${ }^{3}$ (kappa: 0.3466); however, it differs from the agreement reports of Flores-Nava et al. ${ }^{17}$ in pediatric patients, who report a similarity of $72.2 \%$ between the surgeon and the pathologist reports, which contrasts with the similarity of $49 \%$ in our study.

In general, surgeons and pathologists diagnose more phlegmonous AA (48.5 and $53.5 \%$, respectively). There was also little difference between macroscopic and histopathological diagnoses in complicated phases (12.5 and $11 \%$, respectively), with $100 \%$ effectiveness when classifying AA as complicated, similar to the $96.7 \%$ reported by Pourhabibi et al. ${ }^{23}$ in 342 patients.

Failure in complicated AA diagnosis has importance due to involvement in therapeutics, number of hospitalization days and antibiotic treatment duration. False negatives (53 cases, 26.5\%) that were underdiagnosed, i.e., macroscopically classified in a lower phase in relation to histopathology report, received suboptimal antibiotic therapy, which leads to assume that a higher rate of surgical morbidity could occur (more surgical site infections, abscesses or other complications) in many cases, although a deeper evaluation should be carried out to assess this situation, which was not part of this work. The false positives (49 cases, 24.5\%) that were overdiagnosed had excessive hospital stay and antibiotic treatment, which is probably due to excessive caution in order to prevent subsequent complications.

At the time, with few diagnostic means, McBurney²4 proposed that rapid surgical intervention to ensure $A A$ non-progression is much safer than delaying surgical treatment, a legacy which persists to date under the phrase "when in doubt, do the obvious", i.e., laparotomy; a phrase that has been adopted both in our general surgery department and quite surely in many other hospitals, which guarantees us to somehow avoid procedures that imply greater morbidity and mortality for the patient, which is and always will be the priority for us $^{24,25}$.

\section{Conclusion}

A low agreement (kappa: 0.18) was obtained in AA diagnosis between surgeons and pathologists when it was classified by phases. Taking this into account, ideally, there should be a good (kappa: $>0.7$ ) or excellent (kappa:> 0.8) agreement between postoperative macroscopic diagnosis made by the surgeon and histopathological diagnosis made by the pathologist of AA cases and their phases or stages, since postoperative therapy depends on an adequate diagnosis issued by the surgeon when performing the surgical procedure.

\section{Recommendations}

- The surgeon should be more careful with macroscopic findings, in order to refine postoperative diagnosis

- Histopathological report should be issued promptly in order to adjust inpatient drug treatment and on an outpatient basis if necessary.

- There should be greater communication between general surgery and pathology departments, and in case of any doubt, joint sessions should be held.

\section{Acknowledgements}

To HOSGENAES, for the support provided for the development of this research work.

\section{Conflict of interests}

The authors declare that they have no conflicts of interest.

\section{References}

1. Comité de elaboración de guías de práctica clínica. Guía de práctica clínica Apendicitis aguda. AMCG A.C. Ciudad de México; 2014. p. 1-25.

2. Ates MF, Khander A, Steigman SA, Tracy TF Jr., Luks FI. Use of white blood cell count and negative appendectomy rate. Pediatrics. 2014;133:e39-44.

3. Segovia Lohse HA, Figueredo Thiel SJ. Surgical-pathologic concordance in the diagnosis of the acute appendicitis. An Fac Cienc Med. (Asunción). 2012;45:35-46.

4. Guzmán-Valdivia GG. Una clasificación útil en apendicitis aguda. Rev Gastroenterol Mex. 2003;68:261-5.

5. Bliss D, Mckee J, Cho D, Krishnaswami S, Zallen G, Harrison M, et al. Discordance of the pediatric surgeon's intraoperative assessment of pediatric appendicitis with the pathologists report. J Pediatr Surg. 2010;45:1398-403. 
6. Yilmaz M, Akbulut S, Kutluturk K, Sahin N, Arabaci E, Ara C, et al. Unusual histopathological findings in appendectomy specimens from patients with suspected acute appendicitis. World J Gastroenterol. 2013;19:4015-22.

7. Ponsky T, Hafi M, Heiss K, Dinsmore J, Newman K, Gilbert J. Interobserver variation in the assessment of appendiceal perforation. J Laparoendosc Adv Surg Tech. 2009;19(Suppl 1):S15-8.

8. Rossem CC, Schreinemacher MH, Treskes $\mathrm{K}$, van Hogezand RM, van Geloven AA. Duration of antibiotic treatment after appendicectomy for acute complicated appendicitis. Br J Surg. 2014;101:715-9.

9. Kimbrell A, Novosel T, Collins J, Weireter L, Terzian H, Beydoun $\mathrm{H}$, et al Do postoperative antibiotics prevent abscess formation in complicated appendicitis? Am Surg. 2014;80:878-83.

10. Castañeda-Espinosa SD, Molina-Ramírez I, Holguín-Sanabria A, Jaimes-de La Hoz P, Perilla-López M, Pedraza-Carvajal A, et al. Cambio en la clasificación macroscópica de la apendicitis. ¿Tiene algún impacto? Estudio retrospectivo en un hospital universitario pediátrico. Rev Fac Med. 2015;63:243-50

11. Priale PG, Mayta TP. Factors associated with negative appendectomy at a private hospital in Lima - Peru. IMedPub Journals. 2015;11:1-6.

12. Soto-López A, Águila-Melero O, Reyes-Corcho A, Consuegra-Díaz JE Gómez-Baute R. Eficiencia diagnóstica en la apendicitis aguda. Cir Cir. 2003;71:204-9.

13. Suárez MO, Fausto A, Tapia Z. Interaprendizaje de estadística básica. Universidad técnica del norte. Ibarra, Ecuador; 2014(I). p. 15-6.

14. Liang $M$, Andersson R, Jaffe B. The appendix. Schwartz's Principles of surgery. $10^{\text {th }}$ ed. McGraw-Hill Education; 2014(30). p. 1241-62.

15. Macias-Magadan M, Cordero-Olivares A, Fonseca I. Apendicitis: incidencia y correlación clínico patológica. Experiencia de 5 años. Revista Mexicana de Cirugía Pediátrica. 2009;16:170-5.
16. Huacuja-Blanco RR, Ruiz-Campos M, Lemus-Ramírez RI, Villegas-Tovar E, González-Chávez MA, Díaz-Girón G, et al. Factores predictores para apéndice blanca y apendicitis aguda en pacientes sometidos a apendicectomía. Experiencia de dos años en una institución privada. Rev Invest Med Sur Mex. 2015;22:11-8.

17. Flores-Nava G, Jamaica-Balderas ML, Landa-García RA, Parraguirre-Martínez S, Lavalle-Villalobos A. Apendicitis en la etapa pediátrica: correlación clínico-patológica. Bol Med Hosp Infant Mex. 2005;62:196-201.

18. Cichetti DV. Testing the normal approximation and minimal sample size requirements of weighted kappa when the number of categories is large. Applied Psychological Measurement. 1981;5:101-4.

19. Donner A, Eliasziw M. Sample size requirements for reliability studies. Stat Med. 1987;6:441-8

20. Fleiss JL. Comparison of the null distribution of weighted kappa and the C ordinal statistic. Applied Psychological Measurement. 1977;1:195-201.

21. Kulikoff $B$, Vargas $F$, Rodríguez C. Correlación clínico patológica en la apendicitis aguda pediátrica: revisión de 782 casos. Rev Ped Elec. 2009;6:121.

22. Avila Mauricio J, García-Acero M. Apendicitis aguda: revisión de la presentación histopatológica en Boyacá, Colombia. Rev Colomb Cir. 2015;30:125-30

23. Pourhabibi ZN, Javidi PP, Bolandparvaz S, Paydar S. Accuracy of surgeon's intraoperation diagnosis of acute appendicitis, compared with the histopathology results. Bull Emerg Trauma. 2014;2:15-21.

24. McBurney $C$. The incision made in the abdominal wall in cases of appendicitis, with a description of a new method of operating. Ann Surg. 1894;20:38-43.

25. Martínez Mier G, Reyes Devesa HE. Mc Burney: the incision, the point, and the surgeon. Cirujano General. 2007;1:70-5. 